Article

\title{
Hydrothermal Carbonization and Pyrolysis of Sewage Sludge: Effects on Lolium perenne Germination and Growth
}

\author{
Marina Paneque ${ }^{1, *}$, Heike Knicker ${ }^{1}$, Jürgen Kern ${ }^{2}$ and José María De la Rosa ${ }^{1} \mathbb{C}$ \\ 1 Instituto de Recursos Naturales y Agrobiología de Sevilla, Consejo Superior de Investigaciones \\ Científicas (IRNAS-CSIC), Reina Mercedes, Av. 10, 41012 Seville, Spain \\ 2 Leibniz-Institut für Agrartechnik und Bioökonomie, Max-Eyth-Allee 100, 14469 Postdam, Germany \\ * Correspondence: mpaneque@irnas.csic.es; Tel.: +34-9546-24711
}

Received: 13 May 2019; Accepted: 5 July 2019; Published: 9 July 2019

\begin{abstract}
The pyrolysis and hydrothermal carbonization (HTC) of sewage sludge (SS) resulted in products free of pathogens, with the potential for being used as soil amendment. With this work, we evaluated the impact of dry pyrolysis-treated $\left(600^{\circ} \mathrm{C}, 1 \mathrm{~h}\right)$ and HTC-treated $\left(200^{\circ} \mathrm{C}, 260^{\circ} \mathrm{C} ; 0.5 \mathrm{~h}\right.$, $3 \mathrm{~h}$ ) SS on the germination, survival, and growth of Lolium perenne during an 80 day greenhouse experiment. Therefore, the hydrochars and pyrochars were amended to a Calcic Cambisol at doses of 5 and $25 \mathrm{tha}^{-1}$. The addition of sludge pyrochars to the Cambisol did not affect Lolium germination, survival rates or plant yields. However, the use $25 \mathrm{t} \mathrm{ha}^{-1}$ of wood biochar reduced germination and survival rates, which may be related to the low $\mathrm{N}$ availability of this sample. In comparison to the control, higher or equal plant biomass was produced in the hydrochar-amended pots, even though some hydrochars decreased plant germination and survival rates. Among all the evaluated char properties, only the organic and inorganic $\mathrm{N}$ contents of the chars, along with their organic $\mathrm{C}$ values, positively correlated with total and shoot biomass production. Our work demonstrates the $\mathrm{N}$ fertilization potential of the hydrochar produced at low temperature, whereas the hydrochar produced at $260^{\circ} \mathrm{C}$ and the pyrochars were less efficient with respect to plant yields.
\end{abstract}

Keywords: hydrochar; pyrochar; nitrogen; fertilizer; greenhouse experiment; biosolids

\section{Introduction}

Sewage sludge (SS) is a nutrient-rich organic waste, which is produced in increasing amounts. More than 10 million tons (dry weight) are produced annually in Europe [1]. Recycling of SS for agriculture can return N, P, other plant nutrients and organic matter to the soil and may help to reduce the dependency on fossil fuel-consuming synthetic $\mathrm{N}$ fertilizer and non-renewable $\mathrm{P}$ sources. However, its application poses some environmental risks such as nutrient leaching, reduced soil biodiversity, increased greenhouse gas emissions [1], and health risks if not pre-treated properly. One possibility for hygienization of SS before its application to soil represents composting. However, this process consumes not only space and time but also releases greenhouse gases such as $\mathrm{CO}_{2}$ and volatile $\mathrm{N}$. An alternative may be a thermal treatment of SS through pyrolysis or hydrothermal carbonization (HTC). These technologies allow efficient hygienization while concomitantly stabilizing organic $\mathrm{C}$ and $\mathrm{N}$ within a relative short process time. Of course, during thermal treatment greenhouse gases are also released, but this emission may be compensated by recycling the produced thermal energy for other energy requiring purposes. Both pyrolysis and HTC carbonize biomass in low oxygen environments. Temperatures between 300 and $700^{\circ} \mathrm{C}$ are typically used during dry pyrolysis. Hydrochars are typically produced at temperatures between 180 and $250{ }^{\circ} \mathrm{C}$ in the presence of water, which creates autogenous 
pressure. The advantage of transforming SS into hydrochar rather than pyrochar lies in lower energy costs due to the lower process temperatures and the fact that pre-process drying of the feedstock is not necessary. On the other hand, they are considered to be biochemically less stable than biochar [2,3].

Commonly, SS is characterized by a high ash content yielding in pyrolyzed products with organic matter contents which are too low to meet the requirements of the International Biochar Initiative or the European Biochar Certificate [4,5] to be called biochars [6]. Therefore, we will refer to pyrolyzed SS as pyrochar.

Despite the potential of pyrochars and hydrochars to increase the amount of stable carbon stored in soils, its use in agriculture will only be economically feasible if they provide additional benefits such as increasing crop production. Whereas pyrolysis of green waste and wood commonly results in products with a high porosity which may improve some physical properties of the soil [6,7], the pyrolysis of SS turns into carbonized residues with fertilizing potential [8-11].

Solid-state ${ }^{15} \mathrm{~N}$ nuclear magnetic resonance (NMR) spectroscopic studies confirmed that most of the organic $\mathrm{N}\left(\mathrm{N}_{\text {org }}\right)$ in pyro- and hydrochars from SS occurs as heterocyclic $\mathrm{N}$ [10]. Bearing in mind that this so-called black nitrogen (BN) [12] is less bioavailable than inorganic $\mathrm{N}\left(\mathrm{N}_{\mathrm{i}}\right)$, a big advantage of applying such fertilizers lies in the fact that $\mathrm{N}$ losses due to the fact of leaching can be reduced. On the other hand, despite pyrolysis and HTC of SS decreasing P mobility [13], pyrolyzed-SS was able to increase $\mathrm{P}$ contents in plant tissues [11], which demonstrates that at least part of the P was bioavailable. These observations point towards the potential of HTC-treated and pyrolyzed SS to act both as $\mathrm{P}$ and $\mathrm{N}$ sources for plants once applied to the soil.

These promising results are counteracted by the fact that phytotoxic compounds may be formed during thermal treatments. Indeed, negative impacts on germination and seedling growth have been observed in other studies [14-17]. They may be eliminated by well-designed pyrolysis conditions [18] and washing treatments [16]. However, the knowledge about the most appropriate conditions for converting SS into thermally treated products suitable for agriculture is still scarce.

Bearing this in mind, the goal of the present work was to fill those knowledge gaps by complementing a former investigation on the chemical transformation of organic $\mathrm{C}$ and $\mathrm{N}$ forms during HTC and pyrolysis of two different SS [10] with an 80 day greenhouse experiment. The focus of those experiments was to obtain insights on the impact of the application of the respective hydrochars and pyrochars on germination, survival, and biomass production of Lolium perenne. In addition, the char properties were related to the growth of Lolium.

\section{Materials and Methods}

\subsection{Characteristics of the Sample Material}

Two different SS were collected at the Experimental Wastewater Treatment plant (CENTA), located in Carrion de los Céspedes, near Seville, southern Spain. The first sample, further called "A_SS", was a primary sludge produced by the settlement of suspended organic matter in a pond. The second sample, assigned "T_SS", was a secondary sludge accumulated in an extended aeration treatment system and later stored in a thickener, in order to reduce its water content. In addition, "W" pyrochar was yielded from wood chips. Our previous work [10] showed that the material collected from the pond (A_SS) was more humified, thus biochemically stabilized, than that derived from the thickener (T_SS). The total $\mathrm{N}\left(\mathrm{N}_{\mathrm{T}}\right)$ contents of A_SS and T_SS were 19 and $32 \mathrm{~g} \mathrm{~kg}^{-1}$, respectively (Table 1), and occurred mainly as peptides and in amino sugars [10]. Regarding heavy metal content, only Zinc (Zn) for A_SS and Cadmium (Cd) for both A_SS and T_SS slightly exceeded the thresholds established in the Working document on sludge [19] (Table 1). 
Table 1. The $\mathrm{pH}$, organic carbon $\left(\mathrm{C}_{\mathrm{org}}\right)$, total nitrogen $\left(\mathrm{N}_{\mathrm{T}}\right)$, organic nitrogen $\left(\mathrm{N}_{\text {org }}\right)$, inorganic nitrogen $\left(\mathrm{N}_{\mathrm{i}}\right)$ of $\mathrm{N}_{\mathrm{T}}, \mathrm{C}_{\mathrm{org}} / \mathrm{N}_{\mathrm{T}}$ ratio, $\mathrm{P}_{\mathrm{T}}, \mathrm{K}_{\mathrm{T}}, \mathrm{Cd}, \mathrm{Cu}$, and $\mathrm{Zn}$ contents of primary (A_SS) and secondary (T_SS) sewage sludges and the respective hydrochars produced at $200{ }^{\circ} \mathrm{C}\left(\_\mathrm{HTC} \_200\right)$ and $260{ }^{\circ} \mathrm{C}\left(\_\mathrm{HTC} \_260\right)$ for 0.5 and $3 \mathrm{~h}\left(\_0.5\right.$, 3 , respectively), as well as the pyrochars (_Py) [10].

\begin{tabular}{|c|c|c|c|c|c|c|c|c|c|c|c|}
\hline & $\mathrm{pH}$ & $C_{\text {org }}$ & $\mathbf{N}_{\mathbf{T}}$ & $\mathbf{N}_{\text {org }}$ & $\mathrm{N}_{\mathrm{i}}^{\mathrm{a}}$ of $\mathrm{N}_{\mathrm{T}}$ & $\mathrm{C}_{\text {org }} / \mathrm{N}_{\mathrm{T}}$ & $\mathbf{P}_{\mathbf{T}}$ & $\mathbf{K}_{\mathbf{T}}$ & $\mathrm{Cd}$ & $\mathrm{Cu}$ & Zn \\
\hline & & $\mathrm{g} \mathrm{kg}^{-1}$ & $\mathrm{~g} \mathrm{~kg}^{-1}$ & $\mathrm{~g} \mathrm{~kg}^{-1}$ & $\%$ & $(w / w)$ & $\mathrm{g} \mathrm{kg}^{-1}$ & $\mathrm{~g} \mathrm{~kg}^{-1}$ & $\mathrm{mg} \mathrm{kg}^{-1}$ & $\mathrm{mg} \mathrm{kg}^{-1}$ & $\mathrm{mg} \mathrm{kg}^{-1}$ \\
\hline A_SS & 7.4 & 228 & 19.2 & 18.9 & 0.5 & 11.9 & 12.3 & 6.8 & 3.2 & 401 & 1329 \\
\hline A_HTC_200_0.5 & 6.5 & 224 & 16.0 & 15.6 & 2.6 & 14.0 & 13.9 & 7.3 & 3.5 & 423 & 1399 \\
\hline A_HTC_200_3 & 6.5 & 214 & 13.9 & 13.7 & 2.5 & 15.4 & 14.5 & 7.6 & 3.7 & 446 & 1459 \\
\hline A_HTC_260_0.5 & 6.4 & 213 & 11.2 & 10.8 & 1.5 & 19.1 & 15.4 & 8.0 & 4.0 & 477 & 1585 \\
\hline A_HTC_260_3 & 6.6 & 221 & 12.1 & 11.8 & 1.9 & 18.2 & 14.9 & 7.9 & 4.0 & 464 & 1554 \\
\hline A_Py & 9.3 & 134 & 8.6 & 9.0 & 0.0 & 15.5 & 17.0 & 9.5 & 4.6 & 533 & 1766 \\
\hline T_SS & 7.5 & 245 & 32.3 & 31.9 & 0.4 & 7.6 & 16.7 & 6.1 & 3.5 & 418 & 1821 \\
\hline T_HTC_200_0.5 & 6.7 & 233 & 25.0 & 24.5 & 2.2 & 9.3 & 20.0 & 6.8 & 4.2 & 493 & 1983 \\
\hline T_ HTC_200_3 & 6.2 & 233 & 23.9 & 23.7 & 1.4 & 9.7 & 20.8 & 7.1 & 4.3 & 506 & 2017 \\
\hline T_HTC_260_0.5 & 6.3 & 225 & 19.7 & 19.8 & 1.2 & 11.4 & 21.6 & 7.3 & 4.6 & 528 & 2128 \\
\hline T_HTC_260_3 & 6.4 & 224 & 19.0 & 18.7 & 1.4 & 11.8 & 21.6 & 7.6 & 4.8 & 530 & 2162 \\
\hline T_Py & 10.0 & 168 & 16.3 & 16.0 & 0.0 & 10.3 & 25.2 & 9.2 & 5.3 & 618 & 2432 \\
\hline W Py & 9.3 & 829 & 1.80 & n.a. b & n.a. & 922 & 0.7 & 4.5 & n.a. & n.a. & n.a. \\
\hline Soil & 8.4 & 10 & 1 & n.a. & n.a. & 7 & 0.4 & 1.7 & n.a. & n.a. & n.a. \\
\hline
\end{tabular}

${ }^{\mathrm{a}} \mathrm{N}_{\mathrm{i}}$ : inorganic nitrogen (sum of $\mathrm{NH}_{4}-\mathrm{N}, \mathrm{NO}_{2}-\mathrm{N}$, and $\mathrm{NO}_{3}-\mathrm{N}$ in \%); ${ }^{\mathrm{b}}$ n.a.: not available. 
Hydrochars were produced from the primary (A) and secondary (T) SS at $200{ }^{\circ} \mathrm{C}$ (_HTC_200) and $260{ }^{\circ} \mathrm{C}$ (_HTC_260) for 0.5 and $3 \mathrm{~h}\left(\_0.5, \_3\right.$, respectively) as described in Reference [10] in a $1 \mathrm{~L}$ stirred pressure reactor (Parr reactor series 4520, IL, USA). The reaction water was removed through a filter and the material was rinsed with distilled water until the rinsing water turned clear.

To obtain the A and T pyrochars, further called A_Py and T_Py, $200 \mathrm{~g}$ of dry SS were pyrolyzed in a closed steel container in a preheated muffle oven at $600{ }^{\circ} \mathrm{C}$ for $1 \mathrm{~h}$. W_Py carries the European Biochar Certificate and was produced at $600^{\circ} \mathrm{C}$ for $20 \mathrm{~min}$ by Swiss Biochar, Lausanne, Switzerland.

The heavy metals content of the chars tended to increase compared to the non-treated SS; however, only Cd and Zn exceeded the limits [19], similar to the non-treated SS (Table 1). The concentrations of selective volatile organic compounds in process liquid (5-hydroxymethylfurfural 2-furfural, phenol, catechol, cresol, and resorcinol) was measured using a modified ICS 3000 Dionex (Thermo Scientific) with a UV detector (wavelength $280 \mathrm{~nm}$ ) and Knaur Eurosphere II (C 18) column. A 15\% acetonitrile (85\% deionizedwater) was used as mobile phase in the ion chromatography system. Column temperature was set at $23^{\circ} \mathrm{C}$ and flow rate was $1.0 \mathrm{~mL} \mathrm{~min}{ }^{-1}$. No presence of these molecules was found in A_SS, T_SS or in their chars.

According to the International Biochar Initiative [4], the organic $C\left(\mathrm{C}_{\text {org }}\right)$ content of the hydroand pyrochars (Table 1 ) allows their classification as class 3 biochar; however, only the pyrochars fulfill the second requirement of having an atomic $\mathrm{H} / \mathrm{C}$ ratio $<0.7$. A detailed characterization of the organic matter composition is given in Reference [10]. Due to the high $\mathrm{N}$ contents of the source materials, all chars contained considerable amounts of $\mathrm{N}$ between $1 \%$ and $3 \%$, most of which $(>97 \%)$ occurred in an organic form (Table 1). In contrast to the HTC chars, the pyrochars did not concentrate $\mathrm{N}_{\mathrm{i}}$. Total phosphorus $\left(\mathrm{P}_{\mathrm{T}}\right)$ and potassium $\left(\mathrm{K}_{\mathrm{T}}\right)$ contents were determined after digestion with aqua regia $(1: 3 \mathrm{v} / \mathrm{v}$ concentration $\mathrm{HNO}_{3} / \mathrm{HCl}$ ) in a microwave oven (Microwave Laboratory Station Mileston ETHOS 900, Milestone s.r.l., Sorisole, Italy) by inductively coupled plasma-optical emission spectrometer (ICP-OES) spectrophotometer Varian ICP720-ES (Table 1). The $\mathrm{pH}$ of the samples was measured in distilled water $(1: 10, \mathrm{w} / \mathrm{v})$ (Table 1$)$.

\subsection{Greenhouse Experiment}

For the greenhouse experiment, $250 \mathrm{~mL}$ pots $(16 \mathrm{~cm}$ height) were perforated and filled with $250 \mathrm{~g}$ of dried fine earth $(<2 \mathrm{~mm})$ from the Ah horizon of a sandy loamy Calcic Cambisol [20] mixed with amounts equivalent to 5 and $25 \mathrm{tha}^{-1}$ of each char $(0.8$ and $4 \% \mathrm{w} / \mathrm{w}$, respectively) and topped with 25 certified grass seeds (Lolium perenne, ILURO Seeds Company, Barcelona, Spain). The soil derived from the experimental station "La Hampa" of the Instituto de Recursos Naturales y Agrobiología de Sevilla, in the Guadalquivir River Valley (SW Spain; $37^{\circ} 21.32^{\prime}$ N, $6^{\circ} 4.07^{\prime}$ W), Coria del Río, Seville. After sampling, the soil was dried at $40{ }^{\circ} \mathrm{C}$ for $48 \mathrm{~h}$ and sieved $(<2 \mathrm{~mm})$. Small branches, fresh mosses, and plant remains, as well as roots were removed manually. The soil material contained $21 \mathrm{~g} \mathrm{C} \mathrm{kg}^{-1}$, of which $10 \mathrm{~g} \mathrm{~kg}^{-1}$ was attributed to $\mathrm{C}_{\text {org }}$ and $1 \mathrm{~g} \mathrm{~N} \mathrm{~kg}^{-1}$. Its $\mathrm{pH}$ in water was 8.5 and its water holding capacity (WHC), according to Reference [21], was $24 \%$.

For each treatment, four replicates were prepared $(n=4)$. Additionally, 6 controls without any char amendment but with plants were included $(n=6)$. However, of those 6 , only 4 were used for the final analysis. Growing conditions were similar as previously described by Reference [7]. Briefly, soil moisture was adjusted to $60 \%$ of the maximum WHC, the samples were placed in a greenhouse at $25 \pm 2{ }^{\circ} \mathrm{C} / 17 \pm 2{ }^{\circ} \mathrm{C}$ (day/night) maintaining a $14 \mathrm{~h}$ light day ${ }^{-1}$ cycle with the support of growing lights $\left(120 \mu \mathrm{E} \mathrm{m}^{-2} \mathrm{~s}^{-1}\right.$ of photosynthetically active radiation) for 80 days. Average relative humidity of the air in the greenhouse was maintained during the experiment in the range $60 \pm 10 \%$. The position of the samples was changed three times per week to assure comparable light and growing conditions. Chars were dried $\left(40^{\circ} \mathrm{C}\right)$, grounded, and sieved $(<2 \mathrm{~mm})$ prior to being applied to the Calcic Cambisol to avoid possible differences due to the contrasting textures or heterogeneity. No nutrient solution was added. Although the pots were placed on saucers to collect possible excess water, there was no leaching after watering. The same amount of water was added to each sample three times per week, 
which summed up to $145 \mathrm{~L} \mathrm{~m}^{-2}$ at the end of the experiment. This was equivalent to $662 \mathrm{~L} \mathrm{~m}^{-2}$ per year and is similar to the natural average annual precipitation in the region around the experimental station.

The number of living grass shoots was counted after 5, 9, 13, 18, 20, 25, 30, 60, and 80 days. The germination rate was determined from measurements after 20 days of incubation, since it represented the time with the highest number of living plants. The survival rate was calculated by using the 80 count-day data. In addition, the shoots were cut and then left to regrow after 18, 33, 47, and 61 days. The final harvest was after 80 days of incubation. The harvested shoot biomass was dried $\left(48 \mathrm{~h}\right.$ at $40^{\circ} \mathrm{C}$ ) and weighed in order to determine the shoot biomass production. After the experiment, the roots were manually separated from the soil, rinsed with distilled water, dried ( $48 \mathrm{~h}$ at $\left.40^{\circ} \mathrm{C}\right)$, and weighed to determine the root biomass.

\subsection{Statistical Analysis}

All measured variables were submitted to the same statistical analysis using SPSS version 17.0 (SPSS, Chicago, IL, USA). Shapiro-Wilk and Levene tests were used to test for normality and homoscedasticity of the data, respectively. Transformations were applied to meet model assumptions when necessary. A $t$-test was used to identify significant effects between the control and each treatment. The same test was used to evaluate the application dose effect within each char. In addition, an analysis of variance was performed followed by a comparison of means (Tukey's test) to test for significant differences among chars, independently of the dose applied. Effects were considered significant at $p \leq 0.05$.

The $\mathrm{R}$ version 3.4.1 was used to conduct the non-metric multidimensional scaling (NMDS) ordination. Samples variation was represented by an ordination using a Euclidean distance matrix. The "envfit" function in the "vegan" package [22] was used to draw vectors representing chars properties with a statistical effect on Lolium perenne response onto the NMDS ordination. The SigmaPlot version 13.0 was used to plot the previously obtained NMDS data.

\section{Results}

\subsection{Germination and Survival Rates}

Figure 1 shows that the addition of pyrochars to the soil did not affect the germination or survival rate of Lolium perenne. Only W_Py applied at $25 \mathrm{t} \mathrm{ha}^{-1}$ decreased both parameters (Figures 1 and 2). Hydrochars derived from the " $\mathrm{T}$ " sewage sludge showed lower germination and survival rates than the control. In contrast, most of the tested A hydrochars revealed no major impact on the germination or survival rate. In addition, no differences were found when comparing the different production conditions or application doses between each other.

\subsection{Biomass Production}

The biomass production was determined as the sum of the shoot and the root biomass. The use of pyrochars had no effect on biomass production of Lolium perenne except for T_Py applied at $25 \mathrm{tha}^{-1}$ (Figure 3). The total biomass production after hydrochar application was always higher or equal to the control. Note that the greatest biomass was obtained with the hydrochars produced at the lowest temperature for both A and T hydrochars, A_HTC_200 and T_HTC_200, respectively. Residence time seems to have a lower impact than temperature on this parameter. In addition, increasing the application rate did not significantly alter the total biomass production.

\subsection{Root-to-Shoot Ratios}

The pyrochars' addition significantly increased the root-to-shoot (R:S) ratio of Lolium perenne, whereas the presence of A and Thydrochars resulted in lower or equal values than the control (Figure 4). Within hydrochars, production conditions did not affect this parameter; however, the R:S ratio tended to decrease with increasing rates of hydrochar application. These changes were mainly due to the 
higher root biomass in the case of pyrochars and a higher shoot biomass in the case of hydrochars (data not shown).
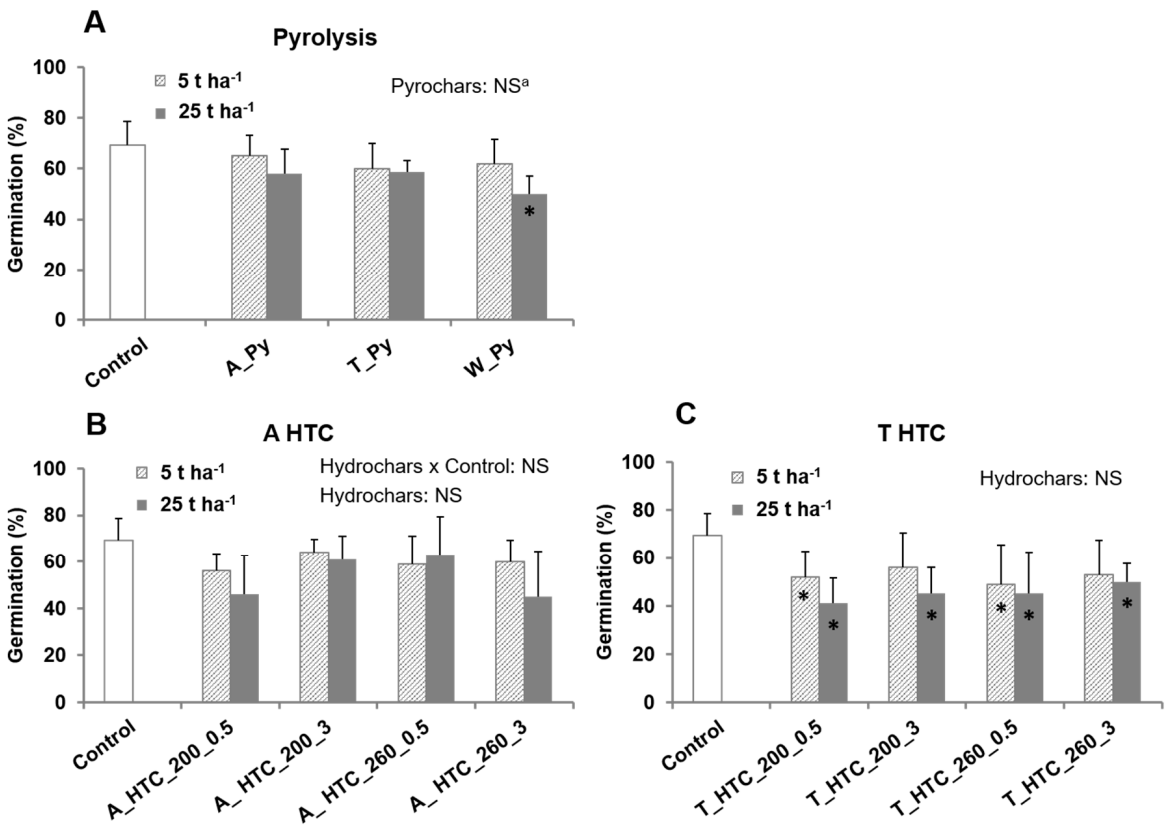

Figure 1. Germination rate (\%) of Lolium perenne in: (A) Control and pyrochars-amended pots, (B) Control and pots amended with hydrochars derived from A_SS and (C) Control and pots amended with hydrochars derived from T_SS. Hydrochars were produced from primary (A_) and secondary ( $\left.\mathrm{T}_{-}\right)$sewage sludges at $200{ }^{\circ} \mathrm{C}\left(\_H T C \_200\right)$ and $260^{\circ} \mathrm{C}\left(\_H T C \_260\right)$ for 0.5 and $3 \mathrm{~h}\left(\_0.5, \_3\right.$, respectively). Pyrochars were produced from primary (A_) and secondary $\left(T_{-}\right)$sewage sludges (_Py). NS: no significance. Asterisks inside the bars show significant differences to the control according to the $t$-test.
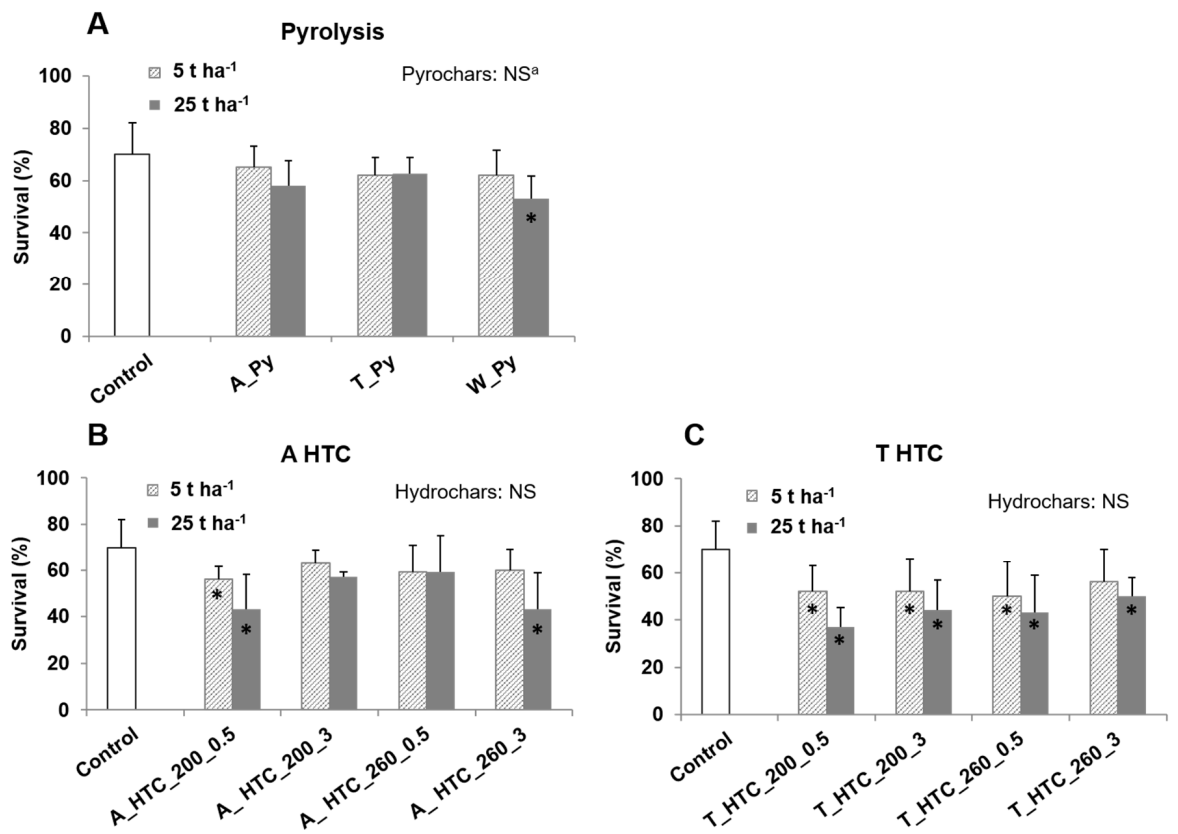

Figure 2. Survival rate (\%) of Lolium perenne in: (A) Control and pyrochars-amended pots, (B) Control and pots amended with hydrochars derived from A_SS and (C) Control and pots amended with hydrochars derived from T_SS. Hydrochars were produced from primary (A_) and secondary (T_) sewage sludges at $200{ }^{\circ} \mathrm{C}$ (_HTC_200) and $260{ }^{\circ} \mathrm{C}$ (_HTC_260) for 0.5 and $3 \mathrm{~h}$ (_0.5,_3, respectively). Pyrochars were produced from primary (A_) and secondary (T_) sewage sludges (_Py). NS: no significance. Asterisks inside the bars show significant differences to the control according to the $t$-test. 


\section{A}

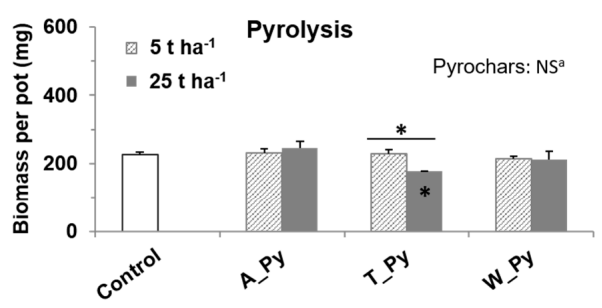

B

A HTC

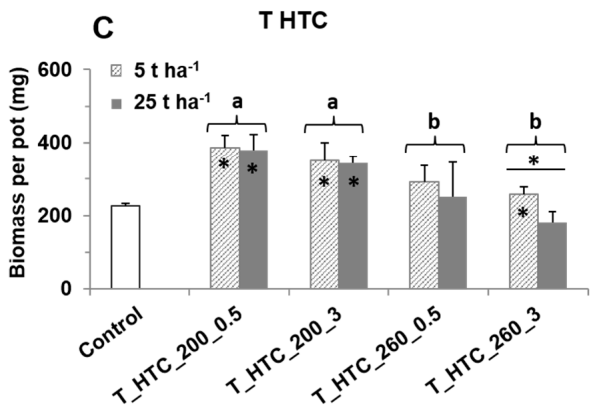

Figure 3. Biomass production per pot (mg) of Lolium perenne in: (A) Control and pyrochars-amended pots, (B) Control and pots amended with hydrochars derived from A_SS and (C) Control and pots amended with hydrochars derived from T_SS. Hydrochars were produced from primary (A_) and secondary $\left(\mathrm{T}_{-}\right)$sewage sludges at $200{ }^{\circ} \mathrm{C}$ (_HTC_200) and $260^{\circ} \mathrm{C}$ (_HTC_260) for 0.5 and $3 \mathrm{~h}$ (_0.5, _3, respectively). Pyrochars were produced from primary (A_) and secondary (T_) sewage sludges (_Py). NS: no significance. Asterisks inside the bars show significant differences to the control according to the $t$-test. The above-line asterisks indicate significant differences among doses according to the $t$-test. The letters show significant differences among treatments according to Tukey's test.
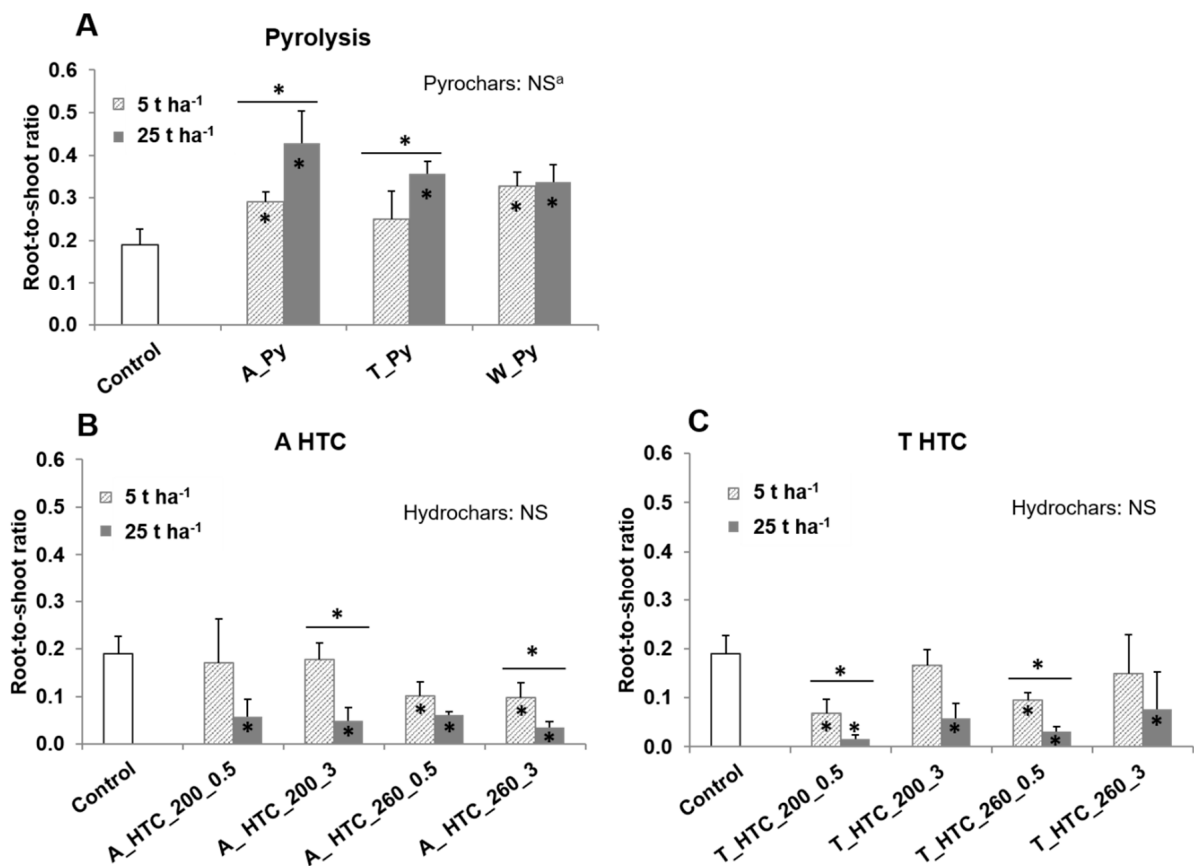

Figure 4. Root-to-shoot ratio of Lolium perenne in: (A) Control and pyrochars-amended pots, (B) Control and pots amended with hydrochars derived from A_SS and (C)Control and pots amended with hydrochars derived from T_SS. Hydrochars were produced from primary (A_) and secondary (T_) sewage sludges at $200{ }^{\circ} \mathrm{C}$ (_HTC_200) and $260{ }^{\circ} \mathrm{C}$ (_HTC_260) for 0.5 and $3 \mathrm{~h}$ (_0.5,_3, respectively). Pyrochars were produced from primary (A_) and secondary (T_) sewage sludges (_Py). NS: no significance. Asterisks inside the bars show significant differences with the control according to the $t$-test. The above-line asterisks indicate significant differences among doses according to the $t$-test. 


\subsection{Relationship between Plant Response and Chars' Properties}

The NMDS graph showed that carbonization type had an overall effect on all parameters since pyrochars were separated from hydrochars (Figure 5). Pyrochars were characterized by higher R:S ratios together with higher root biomass, and to a lower extent, by higher germination and survival rates than hydrochars. In contrast, hydrochars were characterized by larger shoot and total biomass per plant. Regarding the feedstock type, $\mathrm{T}$ hydrochars showed larger shoots and total plant biomass than A hydrochars. In addition, total biomass per plant and shoot biomass significantly correlated with increased $\mathrm{N}_{\mathrm{i}}$ and $\mathrm{N}_{\text {org }}$ contents of the chars. To a lower extent, total biomass per plant and shoot biomass also correlated with increased $\mathrm{C}_{\text {org }}$ levels of the chars. The $p$-values of the abovementioned correlations were less or equal to 0.01 . The $\mathrm{C}_{\text {org }} / \mathrm{N}$ ratio, $\mathrm{P}_{\mathrm{T}}$, and $\mathrm{K}_{\mathrm{T}}$ parameters showed $p$-values higher than 0.01 , and hence, were not considered significant variables.

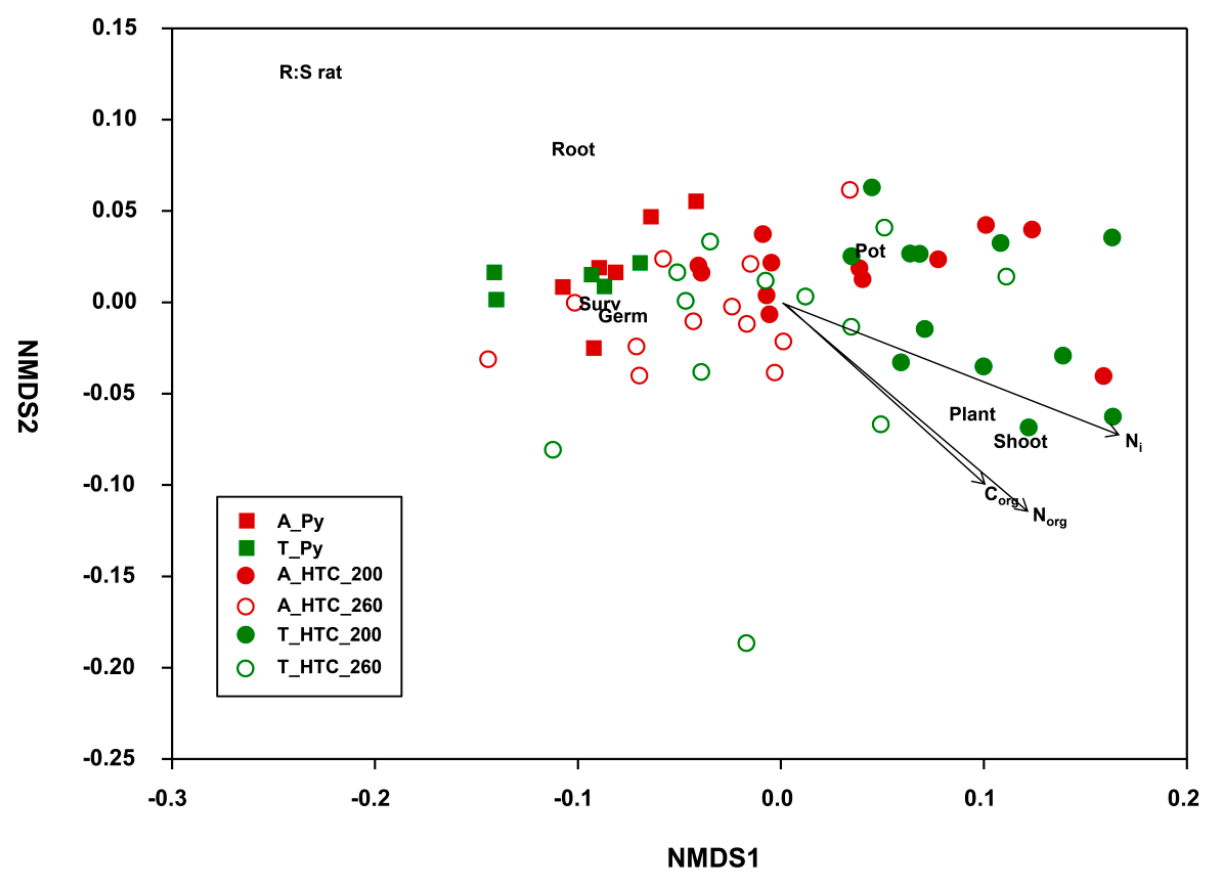

Figure 5. Non-metric multidimensional scaling (NMDS) ordination indicates how the different thermally treated sewage sludges (SS) impact on Lolium-measured parameters. R:S rat: root-to shoot ratio; Roots: roots biomass per plant; Surv: survival rate; Germ: germination rate; Pot: total biomass per pot; Plant: total biomass per plant; Shoot: shoot biomass per plant. Char properties significantly fitting onto the NMDS are shown as vectors $(p<0.01)$. $\mathrm{N}_{\mathrm{i}}$ : inorganic nitrogen; $\mathrm{N}_{\text {org }}$ : organic nitrogen; Corg: organic carbon. Goodness of fit was 0.05 .

\section{Discussion}

\subsection{Germination and Survival Rates}

Our data did not allow an unbiased assignment of factors causing the observed differences in germination and survival rates between hydrochars and pyrochars. The germination rates of Lolium perenne were similar to those previously obtained using biochars produced from different vegetation residues as an amendment to the same Calcic Cambisol [7]. Considering that both SS-derived hydrochars and pyrochars showed $\mathrm{Cd}$ and $\mathrm{Zn}$ values slightly higher than the limits and that only the hydrochars decreased the germination rate, the presence of heavy metals does not explain our results. A decrease in germination after addition of hydrochars has also been observed by others [14-17] and was attributed to phytotoxic volatile organic compounds adsorbed on the surface of the hydrochar. These compounds are mostly water soluble and can be removed by washing the hydrochars with distillate water [16] but soluble nutrients are expected to be at least partially lost during this process. 
The fermentation of hydrochars in an anaerobic biogas reactor has also been proposed to eliminate toxic compounds since it avoids the loss of nutrients [23,24]. However, analysis of our chars prior to incubation did not indicate the presence of HMF, furfural, resorcinol, catechol, phenol, and kresol. Thus, either other non-measured phytotoxic compounds were present in our hydrochars or other factors were responsible. Previous works have also found diverse germination responses among hydrochars produced from different feedstocks $[14,16]$.

Dry pyrolysis performed at temperatures greater than $500{ }^{\circ} \mathrm{C}$ in appropriate pyrolysis reactors reduces the presence of volatile compounds, including polycyclic aromatic compounds and other phytotoxics [25]. Thus, the possible negative impact of pyrochars on germination rates should be less prominent than that of hydrochars. Previous works have shown both neutral and positive effects of pyrochars $[7,15,17,26]$. This is in agreement with our results indicating no major impact of pyrochar addition except for W_Py applied at $25 \mathrm{tha}^{-1}$. This effect caused by W_Py could be due to its extremely high aromaticity $\left(\mathrm{H} / \mathrm{C}_{\mathrm{at}} \leq 0.4 ;[10]\right)$ together with the probable immobilization of nitrogen, especially when adding the highest dose of this amendment $(\mathrm{C} / \mathrm{N}=922$; Table 1$)$.

\subsection{Biomass Production and Chars Properties}

Despite some hydrochars decreasing the survival rate of Lolium perenne, the total biomass production was always higher or equal in the hydrochar amended soils, compared to the control. This is best explained by the size of the remaining plants, since hydrochars tended to increased biomass production per plant (data not shown). However, our pyrochars had no effect on biomass production. The latter is in contrast to Reference [7] who observed a significant increase of Lolium perenne yields in pyrochar amended soils compared to the control. However, here it has to be taken into account that in the former study, inorganic $\mathrm{N}$ fertilizer was added.

The positive correlation between $\mathrm{N}_{\mathrm{i}}$ and $\mathrm{N}_{\mathrm{org}}$ contents of the chars with the total and shoot biomass production per plant suggests that the availability of nitrogen of the chars represents an important factor determining the additional growth of Lolium in the amended soils. Accordingly, the pyrochars showed the lowest $\mathrm{N}_{\text {org }}$ contents along with absence of $\mathrm{N}_{\mathrm{i}}$, which is in line with the lack of increase of Lolium biomass production. The hydrochars produced at $260^{\circ} \mathrm{C}$ exhibited higher $\mathrm{N}_{\mathrm{org}}$ than the pyrochars and contained some $\mathrm{N}_{\mathrm{i}}$ which may explain the slight increase of plant biomass production. However, amendment of the hydrochars produced at $200{ }^{\circ} \mathrm{C}$, containing the highest concentrations of $\mathrm{N}_{\text {org }}$ and $\mathrm{N}_{\mathrm{i}}$, yielded the highest amount of Lolium biomass. This is in line with former experiments showing that green-waste-derived hydrochars produced at $200{ }^{\circ} \mathrm{C}$ also produced higher plant yields than hydrochars produced at higher temperatures [27].

In contrast to $\mathrm{N}$, the $\mathrm{P}_{\mathrm{T}}$ and $\mathrm{K}_{\mathrm{T}}$ contents of the chars revealed no correlation with growth parameters. Either the soil already contained sufficient plant-available $\mathrm{P}$ and $\mathrm{K}$ prior to char application or the $\mathrm{P}$ and $\mathrm{K}$ of the chars were less plant available. In both cases, our results indicated that factors other than $\mathrm{P}_{\mathrm{T}}$ and $\mathrm{K}_{\mathrm{T}}$ contents had a stronger impact on plant growth. The correlation of $\mathrm{C}_{\mathrm{org}}$ contents of the chars with the total and shoot biomass production may be due to the improvement of some soil physical properties, such as a decrease in soil density, an increase of the soil water holding capacity or providing a habitat for soil microorganisms. Note that hydrochars exhibited higher $\mathrm{C}_{\text {org }}$ contents, and thus, higher biomass production than pyrochars. Since the latter are expected to exhibit a higher biochemical stability than hydrochars, one has to keep in mind that increasing the potential of soils to act as a $\mathrm{C}$ sink via addition of charcoal does not necessarily coincide with enhancement of biomass production.

\subsection{Root-to-Shoot Ratios and Char Properties}

Although pyrochar addition had no impact on Lolium biomass production, their presence increased their R:S ratios compared to the control. Considering that increased R:S ratios have been observed when growth is limited by $\mathrm{N}$ or P supply [28], our observation may be related to the absence of $\mathrm{N}_{\mathrm{i}}$ in our pyrochars. This deficiency may have been increased by adsorption of $\mathrm{NO}_{3}{ }^{-}$and $\mathrm{NH}_{4}{ }^{+}$from the soil solution to the char surface as it was suggested to occur for some biochars $[29,30]$. 
Hydrochars applied at $25 \mathrm{t} \mathrm{ha}^{-1}$ showed lower R:S ratios than the control, whereas the $5 \mathrm{tha}^{-1}$ application rate produced no significant impact or a lower decrease of this parameter. In general, when nutrient availability increases, plants can develop their aboveground vegetation in detriment to their subsoil part because less effort is required to acquire nutrients [31]. This is in agreement with our results, since char amendment with $25 \mathrm{tha}^{-1}$ delivered higher nutrients levels than addition of $5 \mathrm{tha} \mathrm{t}^{-1}$.

\subsection{Fertilization Potential of Thermally Treated SS}

This work indicates that low-temperature HTC of SS results in a product with N fertilization potential, whereas chars yielded from HTC with higher temperatures and pyrolysis do not exhibit the same suitability. This potential depends on the amount of $\mathrm{N}_{\mathrm{i}}$ contained in the chars together with the bioavailability of their organic $\mathrm{N}$. Whereas $\mathrm{N}_{\mathrm{i}}$ provides fast and immediate $\mathrm{N}$ fertilization, the degradation rate of the organic $\mathrm{N}$ compounds determines the slow-release $\mathrm{N}$ fertilization potential of the amendments. Our previous work [10] showed that organic N in SS occurred mainly in peptide-like structures, part of which may be easily degradable. During both HTC and pyrolysis, these compounds were partially transformed into N-heterocyclic aromatic entities [32], which are microbiologically less accessible. This transformation was more efficient for pyrolysis than for HTC, which suggested a quicker degradation of the $\mathrm{N}_{\text {org }}$ in hydrochars than in pyrochars. Therefore, not only the total nutrient content values but also their speciation should be considered since their bioavailability from chars is modified with processing conditions.

In addition, it also has to be considered that the same hydrochars/pyrochars may exhibit a different crop response depending on the crop type as well as on the soil properties and the climatic conditions $[33,34]$.

\section{Conclusions}

The pyrolysis process and conditions together with the composition of the sludge were determinant in the properties of the resulting chars and therefore in their applicability as soil amendment. This study showed that although the problem of reduced germination after HTC application still has to be solved, SS-derived hydrochars have the potential to be used as soil amendment with immediate fertilizing effect. Bearing in mind that plant growth parameters correlated better with $\mathrm{N}$ than with $\mathrm{P}$ and $\mathrm{K}$ contents, the increase of plant yields in the hydrochar amended pots is best explained by the concomitant presence of $\mathrm{N}_{\mathrm{i}}$ and easily available organic $\mathrm{N}$ forms. However, further and long-term experiments are needed to discern if the presence of less microbially accessible $\mathrm{N}$ from the pyrochars may turn into an advantage for crops which need low but constant $\mathrm{N}$ fertilization.

From an energetic, and thus, economic point of view, HTC may be advantageous over dry pyrolysis since drying of the SS prior to its thermal treatment can be avoided. In addition, lower temperatures have to be applied during HTC, which considerably reduce the costs for energy. Our studies reveal further that hydrochars produced at $200{ }^{\circ} \mathrm{C}$ caused higher plant growth than those yielded at $260{ }^{\circ} \mathrm{C}$, which allows even less energy consumption. In addition, aside from economic considerations, the role of low temperature hydrochar as $\mathrm{N}$-supplier may be of environmental interest since the use of mineral fertilizer could be reduced and the release of greenhouse gases into the atmosphere occurring during disposal of untreated SS can be avoided.

Author Contributions: M.P., H.K. and J.M.D.l.R. conceived the work. J.K. provided the facilities to produce the hydrochars and pyrochars from sewage sludge and carried out the production M.P. carried out the incubation experiment, laboratory analyses and edited the manuscript. All authors contributed to the interpretation of the data and to drafting the manuscript.

Funding: This research was funded by the Spanish Ministry of Economy and Competitiveness, AEI/FEDER funds of the European Union (projects PCGL2012-37041, CGL2015-64811-P and CGL2016-76498-R) and the Spanish Ministry of Education, Culture and Sport (Marina Paneque FPU fellowship, FPU 13/05831).

Acknowledgments: Carlos Aragón and the Experimental Wastewater Treatment plant (CENTA) are acknowledged for providing the sewage sludges. Ulf Lüder is thanked for his assistance during the production of the chars. Marta Velasco-Molina is gratefully acknowledged for her technical assistance. 
Conflicts of Interest: The authors declare no conflict of interest.

\section{References}

1. Milieu Ltd.; WRc and Risk; Policy Analysts Ltd. (RPA). Environmental, Economic and Social Impacts of the Use of Sewage Sludge on Land. Final Report, Part I: Overview Report. Available online: http://ec.europa.eu/ environment/archives/waste/sludge/pdf/part_i_report.pdf (accessed on 1 April 2019).

2. Lehmann, J.; Joseph, S. Biochar for Environmental Management: Science and Technology, 2nd ed.; Earthscan: London, UK, 2015.

3. Libra, J.; Ro, K.; Kammann, C.; Funke, A.; Berge, N.; Neubauer, Y.; Titirici, M.; Fuhner, C.; Bens, O.; Kern, J.; et al. Hydrothermal carbonization of biomass residuals: A comparative review of the chemistry, processes and applications of wet and dry pyrolysis. Biofuels 2011, 2, 89-124. [CrossRef]

4. International Biochar Initiative. Standardized Product Definition and Product Testing Guidelines for Biochar that is Used in Soil: Version Number 2.1. 2015. Available online: https://www.biochar-international.org/wpcontent/uploads/2018/04/IBI_Biochar_Standards_V2.1_Final.pdf (accessed on 1 April 2019).

5. European Biochar Foundation. European Biochar Certificate-Guidelines for a Sustainable Production of Biochar: Version 8E 2019. Available online: http://www.european-biochar.org/biochar/media/doc/ebcguidelines.pdf (accessed on 1 April 2019).

6. Bachmann, H.J.; Bucheli, T.D.; Dieguez-Alonso, A.; Fabbri, D.; Knicker, H.; Schmidt, H.P.; Ulbricht, A.; Becker, R.; Buscaroli, A.; Buerge, D.; et al. Toward the standardization of biochar analysis: The COST Action TD1107 interlaboratory comparison. J. Agric. Food Chem. 2016, 64, 513-527. [CrossRef] [PubMed]

7. De la Rosa, J.M.; Paneque, M.; Miller, A.Z.; Knicker, H. Relating physical and chemical properties of four different biochars and their application rate to biomass production of Lolium perenne on a Calcic Cambisol during a pot experiment of 79 days. Sci. Total Environ. 2014, 499, 175-184. [CrossRef] [PubMed]

8. Chan, K.Y.; van Zwieten, L.; Meszaros, I.; Downie, A.; Joseph, S. Agronomic values of green waste biochar as a soil amendment. Aust. J. Soil Res. 2007, 45, 629-634. [CrossRef]

9. Chan, K.Y.; van Zwieten, L.; Meszaros, I.; Downie, A.; Joseph, S. Using poultry litter biochars as soil amendments. Aust. J. Soil Res. 2008, 46, 437-444. [CrossRef]

10. Paneque, M.; De la Rosa, J.M.; Kern, J.; Reza, M.T.; Knicker, H. Hydrothermal carbonization and pyrolysis of sewage sludges: What happen to carbon and nitrogen? J. Anal. Appl. Pyrolysis 2017, 128, 314-323. [CrossRef]

11. Frišták, V.; Pipíška, M.; Soja, G. Pyrolysis treatment of sewage sludge: A promising way to produce phosphorus fertilizer. J. Clean. Prod. 2018, 172, 1772-1778. [CrossRef]

12. Knicker, H. "Black nitrogen"-An important fraction in determining the recalcitrance of charcoal. Org. Geochem. 2010, 41, 947-950. [CrossRef]

13. Huang, R.; Tang, Y. Evolution of phosphorus complexation and mineralogy during (hydro)thermal treatments of activated and anaerobically digested sludge: Insights from sequential extraction and P K-edge XANES. Water Res. 2016, 100, 439-447. [CrossRef] [PubMed]

14. Jandl, G.; Eckhardt, K.U.; Bargmann, I.; Kücke, M.; Greef, J.M.; Knicker, H.; Leinweber, P. Hydrothermal carbonization of biomass residues: Mass spectrometric characterization for ecological effects in the soil-plant system. J. Environ. Qual. 2013, 42, 199-207. [CrossRef]

15. Busch, D.; Kammann, C.; Grünhage, L.; Müller, C. Simple biotoxicity tests for evaluation of carbonaceous soil additives: Establishment and reproducibility of four test procedures. J. Environ. Qual. 2012, 41, 1023-1032. [CrossRef] [PubMed]

16. Bargmann, I.; Rillig, M.C.; Buss, W.; Kruse, A.; Kuecke, M. Hydrochar and biochar effects on germination of spring barley. J. Agron. Crop Sci. 2013, 199, 360-373. [CrossRef]

17. Thuille, A.; Laufer, J.; Höhl, C.; Gleixner, G. Carbon quality affects the nitrogen partitioning between plants and soil microorganisms. Soil Biol. Biochem. 2015, 81, 266-274. [CrossRef]

18. Buss, W.; Mašek, O. Mobile organic compounds in biochar-A potential source of contamination - Phytotoxic effects on cress seed (Lepidium sativum) germination. J. Environ. Manag. 2014, 137, 111-119. [CrossRef] [PubMed]

19. European Commission. Working Document on Sludge. 3rd Draft; ENV.E.3/ LM; Directorate-General for the Environment: Brussels, Belgium, 2000. 
20. IUSS Working Group WRB. World Reference Base for Soil Resources 2014, Update 2015 International Soil Classification System for Naming Soils and Creating Legends for Soil Maps. World Soil Resources Reports No. 106. FAO: Rome. Available online: http://www.fao.org/3/i3794en/I3794en.pdf (accessed on 1 April 2019).

21. Veihmeyer, F.J.; Hendrickson, A.H. Methods of measuring field capacity and wilting percentages of soils. Soil Sci. 1949, 68, 75-94. [CrossRef]

22. Oksanen, J.; Blanchet, F.G.; Kindt, R.; Legendre, P.; Minchin, P.R.; O’Hara, R.B.; Simpson, G.L.; Solymos, P.; Stevens, M.H.H.; Wagner, H. Vegan: Community Ecology Package Version 2.4-4. 2015. Available online: http://cran.r-project.org/ (accessed on 27 February 2019).

23. Mumme, J.; Srocke, F.; Heeg, K.; Werner, M. Use of biochars in anaerobic digestion. Bioresour. Technol. 2014, 164, 189-197. [CrossRef] [PubMed]

24. Lanza, G.; Stang, A.; Kern, J.; Wirth, S.; Gessler, A. Degradability of raw and post-processed chars in a two-year field experiment. Sci. Total Environ. 2018, 628-629, 1600-1608. [CrossRef] [PubMed]

25. De la Rosa, J.M.; Paneque, M.; Hilber, I.; Blum, F.; Knicker, H.; Bucheli, T.D. Assessment of polycyclic aromatic hydrocarbons in biochar and biochar-amended agricultural soil from Southern Spain. J. Soils Sediments 2016, 16, 557-565. [CrossRef]

26. Free, H.F.; McGill, C.R.; Rowarth, J.S.; Hedley, M.J. The effect of biochars on maize (Zea mays) germination. N. Z. J. Agric. Res. 2010, 53, 1-4. [CrossRef]

27. Fang, J.; Gao, B.; Chen, J.; Zimmerman, A.R. Hydrochars derived from plant biomass under various conditions: Characterization and potential applications and impacts. Chem. Eng. J. 2015, 267, 253-259. [CrossRef]

28. Andrews, M.; Sprent, J.I.; Raven, J.A.; Eady, P.E. Relationships between shoot to root ratio, growth and leaf soluble protein concentration of Pisum sativum, Phaseolus vulgaris and Triticum aestivum under different nutrient deficiencies. Plant Cell Environ. 1999, 22, 949-958. [CrossRef]

29. Spokas, K.A.; Novak, J.M.; Venterea, R.T. Biochar's role as an alternative N fertilizer: Ammonia capture. Plant Soil 2012, 350, 35-42. [CrossRef]

30. Nelissen, V.; Rütting, T.; Huygens, D.; Staelens, J.; Ruysschaert, G.; Boeckx, P. Maize biochars accelerate short-term soil nitrogen dynamics in a loamy sand soil. Soil Biol. Biochem. 2012, 55, 20-27. [CrossRef]

31. Ågren, G.I.; Franklin, O. Root:shoot ratios, optimization and nitrogen productivity. Ann. Bot. 2003, 92, 795-800. [CrossRef] [PubMed]

32. De la Rosa, J.M.; Knicker, H. Bioavailability of N released from N-rich pyrogenic organic matter: An incubation study. Soil Biol. Biochem. 2011, 43, 2368-2373. [CrossRef]

33. Jeffery, S.; Abalos, D.; Prodana, M.; Bastos, A.C.; Groenigen, J.W.; Hungate, B.A.; Verheijen, F. Biochar boosts tropical but not temperate crop yields. Environ. Res. Lett. 2017, 12, 053001. [CrossRef]

34. Paneque, M.; De la Rosa, J.M.; Franco-Navarro, J.D.; Colmenero-Flores, J.M.; Knicker, H. Effect of biochar amendment on morphology, productivity and water relations of sunflower plants under non-irrigation conditions. Catena 2016, 147, 280-287. [CrossRef]

(C) 2019 by the authors. Licensee MDPI, Basel, Switzerland. This article is an open access article distributed under the terms and conditions of the Creative Commons Attribution (CC BY) license (http://creativecommons.org/licenses/by/4.0/). 